\title{
Ethical and legal considerations regarding the ownership and commercial use of human biological materials and their derivatives
}

This article was published in the following Dove Press journal:

Journal of Blood Medicine

7 September 2012

Number of times this article has been viewed

\section{Carlo Petrini}

Italian National Institute of Health, Rome, Italy
Correspondence: Carlo Petrini Office of the President, Istituto Superiore di Sanità [Italian National Institute of Health], Via Giano della Bella 34, I-00I62 Rome, Italy

Tel +3906 4990402 I; +39069787402 I

Fax +3906 49904303

Email carlo.petrini@iss.it
Abstract: This article considers some of the ethical and legal issues relating to the ownership and use - including for commercial purposes - of biological material and products derived from humans. The discussion is divided into three parts: after first examining the general notion of ownership, it moves to the particular case of possible commercial use, and finally reflects on the case in point in the light of the preceding considerations. Units of cord blood donated altruistically for transplantation and which are found unsuitable for storage and transplantation, or which become unsuitable while stored in biobanks, are taken as an example. These cord-blood units can be discarded together with other biological waste, or they can be used for research or the development of blood-derived products such as platelet gel. Several ethical questions (eg, informed consent, property, distribution of profits, and others) arise from these circumstances. In this regard, some criteria and limits to use are proposed.

Keywords: bioethics, biological specimen banks, cord-blood stem cell transplantation, ethics, informed consent, legislation

\section{Introduction}

The management of biological material (cells and tissues) requires a number of considerations, including technical-scientific, organizational, ethical, and legal. ${ }^{1}$

Biological samples are collected and stored for widely differing purposes:2,3 diagnosis or treatment of the person from whom they are collected (eg, clinical treatment), altruistic donation for therapeutic purposes (eg, blood donation), and donation for purposes of research. The boundaries between purposes may blur, as will be explained below; changing circumstances may lead to samples collected and stored for one purpose being subsequently used for others. ${ }^{4}$

Biological materials may vary according to the purpose for which they are collected. For example, a biological sample collected for therapeutic reasons, such as a biopsy, is very different from those referred to as surgical leftovers. ${ }^{5,6}$ The fate of biological samples will also vary according to the indications specified in the written information given by the physician/researcher to the individual concerned and for which informed consent is given. ${ }^{7}$ Additional differences will depend on the various statutory arrangements of different nations. For example, there are wide variations between states in the ways in which "donations" are considered. ${ }^{8}$

It is thus clear that general guidelines valid for every situation are not feasible. Some generic criteria are certainly valid as a general rule (eg, consent based on adequate information), but other, more specific considerations should be applied on a case-by-case basis. 
One example of how different considerations overlap is that of cord blood, a source of stem cells ${ }^{9,10}$ which is donated for altruistic purposes to the public biobank network for transplantation ${ }^{11}$ and may subsequently be found to be unsuitable for this purpose or become unsuitable after a period of storage. Roughly $90 \%$ of donated cord-blood units are not suitable for use in transplants. ${ }^{12}$

There are several specific circumstances that dictate the need for cord blood to be treated separately rather than as just another biological sample stored in a biobank, including that: ${ }^{13}$

- cord blood is donated for altruistic purposes to be transplanted into persons suffering from diseases that can be cured through a transplant of cord-blood stem cells; $;{ }^{14}$

- the purpose for which the blood was donated may be found (on first testing) to be, or may later become, impossible to achieve, ${ }^{15}$

- informed consent is given not by the individual from whom the sample was taken, but by another person exercising parental authority ${ }^{16}$ (the problems of "parental authority" and of "child assent" recur frequently in the debate on pediatric treatment and research ${ }^{17}$ ); and

- if the unit of blood is initially found to be suitable for transplantation, it enters the national and international networks organized to source and use blood for transplants. ${ }^{18}$

Cord blood that is not suitable for transplantation can be discarded as waste, used for research, or used for the development of blood-derived medicines. ${ }^{19}$ It may be necessary to discard blood units for a number of reasons, such as infection, contamination, or deterioration. If disposal is not necessary for a particular reason, discarding it as refuse is a waste of potentially useful biological material. ${ }^{20}$ The possibility of using cord blood for research must be clearly included in the information given prior to obtaining consent. The issue of using biological samples stored in biobanks for research purposes has been amply addressed in the literature ${ }^{21}$ and will not be considered in this article.

The possible use of discarded blood units to prepare blood-derived products raises several ethical issues, the main issues being informed consent, ownership, patents, and distribution of profits. Most of these ethical dilemmas derive from the controversial situation that arises when human biological material that has been donated for altruistic purposes is used to develop products that can potentially be exploited commercially. The situation thus created is ethically debatable, though it should not be immediately branded unacceptable. The possibility of using such material commercially should be explicitly disclosed during the informed-consent procedure and the donor should have the choice of refusing consent; any units unsuitable for transplantation could accordingly either be discarded or, if consent has been specifically given, used for research. A possible strategy to help avoid the ethically problematic passage from an altruistic donation to the possibly of for-profit use of donated material could be to allow the development of blood-derived products but limit their use to nonprofit therapeutic purposes. The products could, for example, be used for therapeutic purposes within a national health service or within the health care structure in which the blood was originally collected and donated.

The principal elements that should be indicated in consent forms ${ }^{22}$ are included in guidelines published by authoritative organizations, and a proposed model for a consent form is available in the literature. ${ }^{23}$

At present, as we have seen, only a small number of cordblood units are suitable for storage and use in transplants; the possibility of not wasting this precious biological resource is a valid opportunity for making the most of the altruistic gesture of donation..$^{24}$ Blood that is not suitable for transplantation can be processed to give blood components, particularly platelet gel. ${ }^{25}$ This blood product may be of either autologous or allogeneic origin; obtained by aggregating concentrated platelets with calcium and biological or pharmacological proaggregation factors (such as thrombin), this product can be applied topically. This method of using the gel is facilitated by the plasticity and ease of molding it at the site of application, where it encourages and accelerates the repair of both cutaneous and bone tissues. ${ }^{26}$ The gel is used most frequently in maxillofacial surgery, orthopedic and plastic surgeries, and in the treatment of some forms of cutaneous ulcers. Because of its reparative properties, ${ }^{27}$ the potential uses of platelet gel have expanded steadily into different fields of medicine.

More recently, this concentration of platelets has also been used in aesthetic medicine and surgery, for tissue reconstruction and to cure thinning hair, as well as for biorevitalization and skin rejuvenation. However, scientific studies on the use of platelet gel in aesthetic medicine have not been performed according to the rigorous procedures (involving criteria generally used to assess clinical studies and experiments) required to demonstrate the clinical efficacy of these treatments. Specifically, there is still no definite agreement regarding the characteristics or standards of the product, the method of application, or the frequency and seriousness of side-effects and adverse events. 
The following paragraphs examine the legitimacy, in ethical and legal terms, of patenting and exploiting for commercial purposes products derived from units of cord blood that are donated and subsequently discarded. The analysis is divided into three parts: general comments on the ownership of the body and its parts, analysis of patentability, and, finally, an evaluation of special peculiarities.

\section{Ownership of the body and its parts}

The question of the ownership of the body is a very complex one, both in ethical and legal terms. Although there is now nearly worldwide recognition that no person can own another person, as this would constitute slavery and violate Article 4 of the Universal Declaration of Human Rights, ${ }^{28}$ this fundamental right is not always guaranteed in practice; the exploitation of child labor is but one grim example. ${ }^{29}$

The question of a person's ownership of his or her own body is more complicated ${ }^{30}$ and has generated an ample output of literature, including from the philosopher John Locke, according to whom, "every man has a property in his own person." ${ }^{31}$ Other philosophers have proposed a different angle, which Stephen Munzer summed up in the phrase "persons do not own their own bodies but [...] they do have limited property rights in them.."32

In the case of a person's dead body, or of parts of it that have been removed and treated or processed in some way, the scenario is very different. Aside from the philosophical angle, the legal aspect is clearly important. The principle that a deceased human body cannot legally be owned has been in existence for centuries. A 1614 ruling (Haynes' case) ${ }^{33}$ which held that "there can be no property in a corpse," provided the basis of a notion of ownership (or lack thereof) of a corpse that remained unaltered in Common Law until 1908.

In 1908, the case of Doodeward $v$ Spence was heard in the High Court of Australia. ${ }^{34}$ Doodeward had purchased the preserved corpse of a two-headed fetus with the intention of exhibiting it publicly. The local police seized it, whereupon Doodeward appealed and demanded its return. In the resulting legal dispute, the prosecution argued that, because there is no right of ownership in corpses, Doodeward had no legal right to possess one. The Court ruled that the body should be returned to Doodeward because it had undergone "the lawful exercise of work or skill so [...] that it has acquired some attributes differentiating it from a mere corpse awaiting burial." ${ }^{33}$ In other words, since the body had been preserved in a bottle "with spirit," it should no longer be considered a nonentity and was therefore legally protected.
The issue was addressed again in English jurisprudence in 1998 in relation to a theft at the Royal College of Surgeons. With the help of an employee of the College, the artist Anthony-Noel Kelly had stolen some body parts preserved there. The parts were used as molds for sculptures, which were later exhibited in a London art gallery. In order for Kelly to be accused of theft, it was necessary to recognize that body parts could be owned; this was achieved by applying the same exception already established in the Doodeward case. Because the parts had been the object of "skilled work" of a previous generation of surgeons, they could be considered the property of the Royal College of Surgeons. Passing sentence, Mr Justice Rose stated:

We return to the first question, that is to say whether or not a corpse or part of a corpse is property. We accept that, however questionable the historical origins of the principle, it has now been the common law for 150 years at least that neither a corpse, nor parts of a corpse, are in themselves and without more capable of being property protected by rights. ${ }^{35}$

Kelly had to serve 9 months in prison.

Application of the notion of "skill" as an exception to the traditional Common Law approach was taken up again in 2004 by the English High Court in the case of $A B$ and Others $v$ Leeds Teaching Hospital NHS Trust, concerning the preservation of organs. The sentence delivered by Mr Justice Gage stated:

In my judgement the principle that part of a body may acquire the character of property which can be the subject of rights of possession and ownership is now part of our law. In particular, in my opinion, Kelly's case establishes the exception to the rule that there is no property in a corpse where part of the body has been the subject of the application of skill such as dissection or preservation techniques. The evidence in the lead cases shows that to dissect and fix an organ from a child's body requires work and a great deal of skill, the more so in the case of a very small baby [...]. The subsequent production of blocks and slides is also a skilful operation requiring work and expertise of trained scientists. ${ }^{36}$

These cases help us to understand the current legal perspective regarding the legitimate removal of cells, tissues, and organs. It is generally recognized that once the biological material has been removed from the donor, the recipient acquires the right to possession and use, regardless of whether he or she is also the owner. In the event the recipient has also 
processed the material in some way, he or she acquires an additional series of rights, including, at least in some cases, a right of ownership. ${ }^{37}$

The ethical implications of property rights in blood and other parts of the human body are discussed elsewhere. ${ }^{38}$

\section{Possible commercial use General aspects}

The regulatory aspects regarding authorizations for the processing and distribution of blood- and plasma-derived products are highly complex and lie outside the scope of this article. ${ }^{39}$ One of the reasons for their complexity is the fact that these products are often governed both by regulations regarding blood and blood products and by regulations relating to pharmaceutical products, two very different fields from the legislative point of view. ${ }^{40}$ The issues become even more complicated if an international dimension is involved; legislation concerning the donation of biological material and possible remuneration for donors may vary widely in different nations. ${ }^{41}$

Given this situation, the following reflections on the ethical implications relating, in particular, to informed consent and the rights of donors leave aside the regulatory aspects relating to authorizations.

The principle that the human body and its parts cannot, as such, be an object of commercialization or a source of profit is enshrined in numerous authoritative documents. One of the most important is the Council of Europe's Convention for the Protection of Human Rights and Dignity of the Human Being with Regard to the Application of Biology and Medicine: Convention on Human Rights and Biomedicine, ${ }^{42}$ which is a cornerstone of bioethics and biorights..$^{43}$ Article 21 of the Convention, headed "Prohibition of financial gain," states: "The human body and its parts shall not, as such, give rise to financial gain." Article 22, under the heading "Disposal of a removed part of the human body," dictates that:

When in the course of an intervention any part of a human body is removed, it may be stored and used for a purpose other than that for which it was removed, only if this is done in conformity with appropriate information and consent procedures. ${ }^{41}$

The Explanatory Report ${ }^{44}$ to the Convention clarifies the meaning of "body parts," which includes "organs and tissues proper, including blood," but excludes "hair and nails, which are discarded tissues, and the sale of which is not an affront to human dignity." Blood is thus explicitly included in Articles 21 and 22. This is consistent with, among others, European
Directive 2004/23/EC, which uses the term "donor" to designate "every human source, whether living or deceased, of human cells or tissues." 45

Other important documents also reaffirm that the human body and its parts, including blood, ${ }^{46}$ should not give rise to financial gain; some declarations by the United Nations Educational, Scientific and Cultural Organization, particularly the Universal Declaration on the Human Genome and Human Rights, ${ }^{47}$ the International Declaration on Human Genetic Data $^{48}$ and the Universal Declaration on Bioethics and Human Rights, ${ }^{49}$ repeat the principle of non-commercialization and the prohibition of the use of the human body for profit. For example, Article 4 of the Universal Declaration on the Human Genome and Human Rights states that "The human genome in its natural state shall not give rise to financial gains."

Among the documents that refer explicitly to cord blood, the principle of non-commercialization recurs, for example, in "Opinion 19 - Ethical aspects of umbilical cord blood banking," published on March 16, 2004 by the European Group on Ethics in Science and New Technologies (established by the European Commission): "There are several fundamental ethical principles and values which can be considered relevant for the opinion: The principle of respect for human dignity and integrity, which asserts the principle of non-commercialisation of the human body [...]." In fact, the issue of commercialization and financial gain in this document is concerned less with the production of blood products or other patentable products than with the comparison between storage in public biobanks for altruistic purposes and private storage in commercial biobanks. ${ }^{50}$

With regard to possible financial gain, the regulations governing the patentability of biological samples have also to be considered.

A patent is a form of intellectual property in an invention, giving the holder exclusive title to use it. This exclusive right is limited in scope, duration, and geographical area of validity. Any type of invention that satisfies the requisites of novelty and originality and that can be applied industrially can be patented. ${ }^{51}$

For the European Union, the key reference document for the biotechnology sector is Directive 98/44. ${ }^{52}$ According to European Union legislation, the following are patentable, provided they satisfy the requisites of novelty and originality and are susceptible to industrial application: biological material which is isolated from its natural environment or produced by means of a technical process, even if it previously occurred in nature; any technical process by means of 
which biological material is produced, processed, or used, even if it previously occurred in nature; any new application of biological material or of a process already patented; and inventions relating to an element isolated from the human body or otherwise produced by means of a technical process, even if its structure is identical to that of a natural element, provided that its function and industrial use are disclosed in the patent application.

All commercial rights or patents apply to the results of research and not to the samples collected, for which no rights of ownership are typically legally recognized.$^{53}$ The key rights and duties of the promoter of the research, the researcher, and the individual from whom the biological material was taken must be disclosed prior to consent.

It is not within the scope of the present article to examine the ethical issues relating to the possible patenting of human biological materials and derivatives, on which there is in an ample body of literature. ${ }^{54}$ The comprehensive report by the Nuffield Council entitled The Ethics of Patenting DNA ${ }^{55}$ contains useful comments regarding not only DNA, but also other types of biological material, such as blood.

\section{Three significant examples}

Legal disputes regarding the commercial use of biological material or its derivatives are widely discussed in specialist literature. The three well-publicized cases described briefly below concern different circumstances from those that are of interest here, but nonetheless provide useful considerations for the case in point.

\section{Moore $v$ the University of California}

This case concerned John Moore, who in 1976 underwent a splenectomy at the University of California Los Angeles (UCLA) Medical Center. Between 1976 and 1983, John Golde, the medical supervisor of Moore's case, in agreement with a researcher, Shirley Quann, asked Moore repeatedly to return to UCLA for blood tests. On April 11, 1983, Golde asked Moore to sign an informed consent form authorizing Golde to carry out research on blood samples. Golde and Quann used the biological material taken from Moore, which was "of great value in a number of commercial and scientific efforts," but failed to inform Moore. ${ }^{56}$ Golde and Quann developed a cell line from Moore's T-lymphocytes and patented this cell line (registration number 4,438,032). Between 1984 and 1990, the patent earned more than three billion dollars. ${ }^{57}$ When Moore learned of this, he sued Golde, UCLA, and two biotechnology companies, claiming the right to share in the proceeds obtained from the biological material taken from him. The judges of the Supreme Court of California were divided, but they rejected Moore's claim for three main reasons: the lack of precedents to support Moore's claims; California legislation on the disposal of human tissues; and the fact that the patented cells were different from those taken from Moore and could therefore no longer be considered as his property. ${ }^{58}$

\section{Greenberg v Miami Children's Hospital $(\mathrm{MCH})$ Research Institute}

This case was initiated by Daniel Greenberg, who had approached the physician and researcher Rueben Matalon, who was seeking to identify the genes associated with Canavan disease in order to develop a prenatal test. Matalon collected biological material (blood, urine, and tissue samples) donated by Greenberg and other donors. The result was the development of a prenatal diagnostic test, thanks in part to support from several nonprofit organizations. In subsequent research, supported by $\mathrm{MCH}$, Matalon isolated and cloned the gene associated with Canavan disease. $\mathrm{MCH}$ obtained a patent for the gene and related applications, including a prenatal diagnostic test. The annual royalties from the patent amounted to approximately $\$ 350,000$. In 2002, Greenberg and other donors filed a suit against Matalon and $\mathrm{MCH}$, claiming that the donors had not been informed of the developments, as it was their right to be, and that had they known of Matalon's intention of exploiting the genetic material and the test developed from it commercially, they would not have donated their biological material. The Court acknowledged that the physician/researcher always has a duty to provide information and to ask for consent, but held that this duty does not extend to economic interests. ${ }^{59}$ In a note to the sentence, the Court noted that the Code of Medical Ethics of the American Medical Association requires that the physician/researcher should declare his or her economic interests, ${ }^{60}$ but that this did not apply in the case in question as the Code had been adopted after the research had begun. The Court argued that the duty to obtain informed consent, if conceived in line with the plaintiffs' interpretation, would have pernicious effects on scientific research and that "it would give each donor complete control over how medical research is used and who benefits from that research." To impose such a duty retroactively would "chill medical research," as it would force researchers constantly to evaluate whether a "disclosable event" had occurred. The Court further found, as in the Moore case, that a research product developed from human tissue is factually and legally distinct 
from the original tissue and as such becomes the property of the researcher, while the donor retains no rights.

\section{Washington University v Catalona}

William Catalona, a well-known surgeon and researcher, habitually asked his patients for consent to use tissues and other biological material removed during prostate surgery for research. The patients signed one of several consent forms, in which they declared, among other things, that they were aware of making a "free and generous gift" to research that might benefit society and that they waived all rights in the biological material donated and in any product obtained through research on that material ${ }^{61,62}$ (as provided in the Uniform Anatomical Gift $\mathrm{Act}^{63}$ ). The biological bank of Washington University (WU) collected biological samples from approximately 30,000 patients, about 3000 of whom were patients of Catalona. The dispute arose when Catalona transferred a large number of the samples to a private laboratory. The University objected on the grounds that he had taken material of a value of approximately $\$ 100,000$, including about 3500 samples of tissue, 100,000 of blood, and 4000 of DNA. Because of the dispute, Catalona decided to leave WU and accept a position at the Northwestern School of Medicine. He informed his patients of his decision and asked for their authorization to transfer their biological samples to Northwestern. A large portion of the patients consented, but WU refused to authorize the transfer and sued Catalona, claiming ownership of the samples. Numerous patients were involved in the lawsuit and declared themselves in favor of the transfer to Northwestern School of Medicine so that Catalona could continue his research on prostate cancer. They further declared that they had consulted Catalona for medical reasons and had not gone to WU in order for the university to make a profit. They also claimed to retain rights of ownership in the samples.

The Eighth Circuit Court of Appeals held that the patients had donated the biological material for research and no longer retained either property rights in it or the right to authorize its transfer. They had, according to the sentence, donated the material to WU. ${ }^{64}$ This sentence, like the two described above, thus held that the donor loses the rights to ownership and control of the use of biological material as soon as the material is donated for research purposes. ${ }^{65}$

It would seem from these three cases that case law is generally oriented towards recognizing that:

- donors of biological material have a right to be informed of its possible uses and, in particular, of potential commercial spin-offs;
- the right to control the biological material taken from a donor ceases at the moment of donation;

- donors cannot claim rights of "ownership" in biological material; and

- the recipient has the right to commercial exploitation of any products developed from the processing of biological material received, in accordance with current legislation.

\section{The need for guidelines}

Documents that address general ethical issues often provide useful suggestions to deal not only with general problems, but also with more specific situations on a case-by-case basis. However, in order to address specific circumstances, it is important to be able to refer to general operational guidelines.

With regard to cord blood, standards set by accreditation authorities are an essential point of reference for those involved in the collection, storage and use of blood units. ${ }^{66}$ The guidelines provide useful indications for the management of discarded units but do not address the matter of their possible use to develop blood-derived products or their possible commercialization (see, for example, paragraph "D9 disposal" of the NetCord guidelines ${ }^{21}$ on the subject of discarded cord blood units).

With regard to patentability and relevant operational criteria in particularly complex cases such as in the case of cord blood, in which biological material is used to develop products that can potentially be exploited commercially, it is important that even when a patent is granted, detailed information on the limits to possible uses should be indicated. This is recommended, for example, by the Organisation for Economic Co-operation and Development (OECD), which provides that "license agreements should define the roles and responsibilities of the parties in the commercialization, if any, of the products and services arising from the use of the licensed genetic invention" (paragraph 1.8). ${ }^{67}$ Although the guidelines refer to genetic material, the general principle is certainly applicable to other types of biological samples.

\section{Proposed criteria for the case in point}

With reference to yet another authoritative document, it may be helpful to examine paragraph 2.08 ("Commercial use of human tissue") of the Code of Medical Ethics published by the American Medical Association (Council on Ethical and Judicial Affairs) already referred to, ${ }^{59}$ which states: 
Physicians contemplating the commercial use of human tissue should abide by the following guidelines:

1. Informed consent must be obtained from patients for the use of organs or tissues in clinical research.

2. Potential commercial applications must be disclosed to the patient before a profit is realized on products developed from biological materials.

3. Human tissue and its products may not be used for commercial purposes without the informed consent of the patient who provided the original cellular material.

4. Profits from the commercial use of human tissue and its products may be shared with patients, in accordance with lawful contractual agreements.

5. The diagnostic and therapeutic alternatives offered to patients by their physicians should conform to standards of good medical practice and should not be influenced in any way by the commercial potential of the patient's tissue. ${ }^{59}$

The paragraph entitled "Ethical considerations" of the report Who Should Profit from the Economic Value of Human Tissue? An Ethical Analysis ${ }^{68}$ refers mainly to the use of tissues for research purposes rather than to donations given for transplant purposes and subsequently found unsuitable. Some of the comments in the report could nonetheless be applied to cord blood, such as:

Typically, patients who consent to the use of their tissue for biomedical research do so with the expectation that the donated tissue will be used to further scientific knowledge and to enhance the health and well-being of other patients. The tissue is given by the patient as a gift, on the assumption that it will be used in good faith for the medical benefit of others. Patients' perceptions of such donations might be very different if it is known that commercial profits are a potential objective of the research to be conducted. Patients, therefore, cannot provide fully informed consent to the use of their organs or tissues in clinical research unless potential commercial applications of the tissue and its products are disclosed. Disclosure of potential commercial applications is further indicated because of the conflict of interest created by the physician's economic interest in the value of extracted tissue [...]. Patients may fear, for example, that their physician's economic interests will influence the type of care they receive or ultimately result in their exploitation [...]. With respect to the equitable distribution of profits derived from human tissue, patients must be permitted to decline commercial use of products developed from their cellular material, as an exercise of control over the terms and conditions of their participation in clinical research.
Alternatively, patients may choose to share in the profits from commercial ventures that utilize their tissue or its products by entering into contractual agreements with physician researchers. For example, physicians may offer patients a small percentage of any profits that are realized on products derived from the patient's cells.

Although the recommendations of the American Medical Association do not refer explicitly to cord blood, they are a helpful reference for the case in point, particularly where patients' rights and informed consent are concerned. In the case of cord blood, for example, some donors may be prepared to give their consent for potential commercial exploitation, but with certain limitations, such as for exclusively therapeutic purposes, but excluding cosmetic uses.

The ethical problems raised are similar to those associated with another issue that is currently highly debated in specialist literature, by those responsible for healthcare policies, and by public opinion, which is the possibility of compensating so-called donors. ${ }^{69}$ The expression "remunerated donation" is widely used, despite being an obvious example of oxymoron. There is also the problem that the legal framework concerning human biological material is still ill-defined in many nations and must be consolidated. ${ }^{70}$

In light of the above, it would seem appropriate, from the ethical perspective, to recall a crucial aspect regarding possible commercial spin-offs arising from units of cord blood donated for transplantation purposes and subsequently discarded; the biological material is donated, without compensation, for altruistic purposes, such as for transplantation in persons affected by pathologies that can be cured through the use of hematopoietic stem cells, ${ }^{71}$ and any conversion of an altruistic donation into material for commercial use is likely to generate concern. In other words, the fact that the procedure whereby the products are developed from cord blood (particularly platelet gel) may have been patented would seem perfectly legitimate. Nonetheless, the possible exploitation for financial gain of blood donated for altruistic purposes for which consent is not given directly by the person from whom the blood is taken but by another person exercising parental authority may give rise to controversy. Use of the products thus derived could perhaps be restricted to the health care facilities in which the blood units were collected, and their commercialization excluded. This strategy could offer, in both ethical and regulatory terms, a means of reconciling the different concerns raised by the development of potentially commercial blood-derived products from material donated altruistically for therapeutic purposes. The informed consent forms would naturally provide all 
requisite information ${ }^{72}$ and offer both the option of refusing consent to any use that may lead to the development of medicines or blood-derived products and the option to set certain restrictions.

\section{Disclosure}

The author reports no conflicts of interest in this work.

\section{References}

1. Nuffield Council on Bioethics. Human Bodies: Donation for Medicine and Research. London: Nuffield Council on Bioethics; 2011. Available from: http://www.nuffieldbioethics.org/sites/default/files/ Donation_full_report.pdf. Accessed June 1, 2012.

2. Elger BS, Biller-Andorno N, Mauron A, Capron AM, editors. Ethical Issues in Governing Biobanks. Global Perspectives. Aldershot: Ashgate Publishing; 2008.

3. National Bioethics Advisory Commission (NBAC). Research Involving Human Biological Materials: Ethical Issues and Policy Guidance. Springfield, VA: NBAC; 1999. Available from: http://bioethics. georgetown.edu/nbac/hbm_exec.pdf. Accessed June 1, 2012.

4. Warwick RM, Fehily D, Brubaker SA, Eastlund T, editors. Tissue and Cell Donation. An Essential Guide. Chichester: Wiley-Blackwell; 2009.

5. van Diest P. No consent should be needed for using leftover body material for scientific purposes. For. BMJ. 2002;325(7365):648-651.

6. Savulescu J. No consent should be needed for using leftover body material for scientific purposes. Against. BMJ. 2002;325(7365):648-651.

7. Clayton WE. Informed consent and biobanks. J Law Med Ethics. 2005;33(1):15-21.

8. Price D. Human tissue in transplantation and research. A Model Legal and Ethical Donation Framework. Cambridge: Cambridge University Press; 2010.

9. Wyrsch A, dalle Carbonare V, Jansen W, et al. Umbilical cord blood from preterm human fetuses is rich in committed and primitive hematopoietic progenitors with high proliferative and self-renewal capacity. Exp Hematol. 1999;27(8):1338-1345.

10. Kinzfogl JM, Broxmeyer HL. Brief historical overview of hematology, cord blood, and links between the nervous and hematopoietic systems. In: Broxmeyer HE, editor. Cord Blood. Biology, Transplantation, Banking and Regulation. Bethesda, MD: AABB Press (Advancing Transfusion and Cellular Therapies Worldwide); 2011:1-6.

11. Gluckman E, Ruggeri A, Volt F, Cunha R, Boudjedir K, Rocha V. Milestones in umbilical cord blood transplantation. Br J Haematol. 2011;154(4):441-447.

12. Sun J, Allison J, McLaughlin C, et al. Differences in quality between privately and publicly banked umbilical cord blood units: a pilot study of autologous cord blood infusion in children with acquired neurologic disorders. Transfusion. 2010;50(9):1980-1987.

13. Butler MG, Menitove JE. Umbilical cord blood banking: an update. J Assist Reprod Genet. 2011;28(8):669-676.

14. Navarrete $\mathrm{C}$, Contreras M. Cord blood banking: a historical perspective. Br J Haematol. 2009;147(2):236-245.

15. Meyer EA, Hanna KE, Gebbie KM, editors; Committee on Establishing a National Cord Blood Stem Cell Bank Program. Umbilical cord blood banks and banking. Cord Blood - Establishing a National Hematopoietic Stem Cell Bank Program. Washington, DC: The National Academy Press; 2005:75-105.

16. Sayeed A. The moral and legal status of children and parents. In: Miller G, editor. Pediatric Bioethics. Cambridge: Cambridge University Press; 2010:38-53.

17. Petrini C, Lombardini L, Pupella S, Nanni Costa A, Grazzini G. Collection, storage, and allogeneic use of cord blood: informed consent form used by the Italian Biobank Network. Biopreserv Biobanking. 2011;9(3):273-278.
18. Wall DA. Regulatory issues in cord blood banking and transplantation. Best Pract Res Clin Haematol. 2010;23(2):171-177.

19. Cogdell KJ. Saving the leftovers: models for banking cord blood stem cells. Univ Memphis Law Rev. 2009;39(2):229-254.

20. Regan DM. Cord blood banking: the development and application of cord blood banking processes, standards and regulations. In: Broxmeyer HE, editor. Cord Blood. Biology, Transplantation, Banking and Regulation. Bethesda, MD: AABB Press (Advancing Transfusion and Cellular Therapies Worldwide); 2011:633-645.

21. Bordet S, Minh NT, Knoppers B, Isasi R. Use of umbilical cord blood for stem cell research. J Obstet Gynaecol Ca. 2010;32(1): $58-61$.

22. NetCord, Foundation for the Accreditation of Cell Therapy (FACT). NetCord-FACT International Standards for Cord Blood Collection, Banking and Release for Administration. 4th ed. Jan 2010. Available from: www. factweb.org/forms/store/ProductFormPublic/search?action=1\&Product_ productNumber=601. Accessed June 1, 2012.

23. Petrini C, Farisco M. Informed consent for cord blood donation. A theoretical and empirical study. Blood Transfus. 2011;9(3): 292-300.

24. Annas GJ. Waste and longing - the legal status of placental-blood banking. New Engl J Med. 1999;340(19):1521-1524.

25. Parazzi V, Lazzari L, Rebulla P. Platelet gel from cord blood: a novel tool for tissue engineering. Platelets. 2010;21(7):549-554.

26. Everts PA, Knape JT, Weibrich G, et al. Platelet-rich plasma and platelet gel: a review. J Extra Corpor Technol. 2006;38(2):174-187.

27. Greppi N, Mazzucco L, Galetti G, et al. Treatment of recalcitrant ulcers with allogeneic platelet gel from pooled platelets in aged hypomobile patients. Biologicals. 2011;39(2):73-80.

28. United Nations. The Universal Declaration of Human Rights. New York: United Nations; 1948. Available from: http://www.un.org/en/ documents/udhr/. Accessed June 1, 2012.

29. United Nations Childrens' Fund (UNICEF). The State of the World's Children. Special Edition. Celebrating 20 Years of the Convention on the Rights of the Child. New York: UNICEF; 2009. Available from: http://www. unicef.org/rightsite/sowc/fullreport.php. Accessed August 16, 2012.

30. Pattinson SD. Property in human organs and tissue. In: Medical Law and Ethics. Third Edition. London: Sweet and Maxwell; 2009: 516-525.

31. Locke J. Of property. In: The Second Treatise of Civil Government. 1690. Austin, TX: Constitution Society; 1998. Available from: http:// www.constitution.org/j1/2ndtreat.htm. Accessed June 1, 2012.

32. Munzer S. A Theory of Property. New York: Cambridge University Press; 1990:41.

33. Haynes' case (1614) 12 Co Rep 113 77ER.

34. Doodeward v Spence, 6 CLR 406 (1908).

35. $R v$ Kelly \& Lindsay, Q.B. 621 (1999).

36. High Court of Justice. AB and Ors v Leeds Teaching Hospital NHS Trust, Court of Appeal - Queen's Bench Division, March 26, 2004, [2004] EWHC 644 (QB), [2005] Lloyds Rep Med 1, [2004] 2 FLR 365, [2005] 2 WLR 358, [2004] Fam Law 501, [2005] QB 506, [2004]3 FCR 324, [2005] Lloyd's Rep Med 1, (2004) 77 BMLR 145. Available from: http:// high-court-justice.vlex.co.uk/vid/hq-0101462-52945111. Accessed June $1,2012$.

37. Hakimian R, Korn D. Ownership and use of tissue specimens for research. JAMA. 2004;292(20):2500-2505.

38. Petrini C. Is my blood mine? Some comments on the Convention on Human Rights and Biomedicine. Blood Transfus. 2012. In press.

39. Soini S, Aymé S, Matthijs G; Public and Professional Policy Committee and Patenting and Licensing Committee. Patenting and licensing in genetic testing: ethical, legal, and social issues. Eur J Hum Genet. 2008;16(Suppl 1):S10-S50.

40. Valverde JL. The political dimension of blood and plasma derivatives. Pharmaceutical Policy and Law. 2005;7:21-33.

41. Farrugia A, Penrod J, Bult JM. Payment, compensation and replacement - the ethics and motivation of blood and plasma donation. Vox Sang. 2010;99(3):202-211. 
42. Council of Europe. Convention for the Protection of Human Rights and Dignity of the Human Being with Regard to the Application of Biology and Medicine: Convention on Human Rights and Biomedicine. Council of Europe; April 4, 1997; Oviedo, Spain. Available from: http:/ conventions.coe.int/Treaty/en/Treaties/html/164.htm. Accessed June 1, 2012.

43. Kits Nieuwenkamp J. The Convention on Human Rights and Biomedecine. In: Dahl Rendtorff J, Kemp P, editors. Basic Ethical Principles in European Bioethics and Biolaw. Barcelona: Institut Borja de Bioèthica; 2000;2:325-332.

44. Council of Europe. Convention for the Protection of Human Rights and Dignity of the Human Being with Regard to the Application of Biology and Medicine: Convention on Human Rights and Biomedicine. Explanatory report. Strasbourg: Council of Europe; 1997. Available from: http://conventions.coe.int/Treaty/EN/Reports/Html/164.htm. Accessed June 1, 2012.

45. European Parliament, Council of the European Union. Directive 2004/23/EC of the European Parliament and of the Council of March 31, 2004 on setting standards of quality and safety for the donation, procurement, testing, processing, preservation, storage and distribution of human tissues and cells. Official Journal of the European Union. 2004;L102:48-58.

46. O'Mahony B, Turner A. The Dublin Consensus Statement 2011 on vital issues relating to the collection and provision of blood components and plasma-derived medicinal products. Vox Sang. 2012; 102(2):140-143.

47. United Nations Educational, Scientific and Cultural Organization (UNESCO). Universal Declaration on the Human Genome and Human Rights. November 11, 1997. Available from: http://www.unesco.org/ new/en/social-and-human-sciences/themes/bioethics/human-genomeand-human-rights/. Accessed June 1, 2012.

48. United Nations Educational, Scientific and Cultural Organization (UNESCO). International Declaration on Human Genetic Data. Paris, France: UNESCO; 2003. Available from: http://www.unesco.org/new/ en/social-and-human-sciences/themes/bioethics/human-genetic-data/. Accessed June 1, 2012.

49. United Nations Educational, Scientific and Cultural Organization (UNESCO). Universal Declaration on Bioethics and Human Rights. Paris, France: UNESCO; 2005. Available from: http://www.unesco.org/ new/en/social-and-human-sciences/themes/bioethics/bioethics-andhuman-rights/. Accessed June 1, 2012.

50. The European Group on Ethics in Science and New Technologies. Ethical Aspects of Umbilical Cord Blood Banking. The European Group on Ethics in Science and New Technologies; 2004. Available from: http://ec.europa.eu/bepa/european-group-ethics/docs/avis19_en.pdf. Accessed June 1, 2012.

51. Guenin LM. Patents ethics, human life forms. In: Murray TH, Melhman MJ, editors. Encyclopedia of Ethical, Legal, and Policy in Biotechnology. New York: John Wiley \& Sons; 2000;2: 866-880.

52. European Parliament, Council of the European Union. Directive 98/44/ EC of the European Parliament and of the Council of July 6, 1998 on the legal protection of biotechnological inventions. Official Journal of the European Communities. 1998;L213:13-21.

53. Hermerén G. Patents and licensing, international controversies. In: Murray TH, Melhman MJ, editors. Encyclopedia of Ethical, Legal, and Policy in Biotechnology. New York: John Wiley \& Sons; 2000;2: 817-825.

54. Wreen M. Patents. In: Chadwick Ruth F, editor. Encyclopedia of Applied Ethics. 2nd ed. San Diego, CA: Academic Press, 2012;3: 349-358.
55. Nuffield Council on Bioethics. The Ethics of Patenting DNA. London: Nuffield Council on Bioethics; 2002. Available from: http://www. nuffieldbioethics.org/sites/default/files/The $\% 20$ ethics $\% 20$ of $\% 20$ patenting \%20DNA\%20a\%20discussion\%20paper.pdf. Accessed June 1, 2012.

56. Hakimian R, Korn D. Ownership and use of tissue specimens for research. JAMA. 2004;292(20):2500-2505.

57. Gitter DM. Ownership of human tissue: a proposal for federal recognition of human research participants' property rights in their biological material. Wash Lee Law Rev. 2004;61(1):257-345.

58. Moore v Regents of the University of California, 793 P.2d $479(\mathrm{Cal}$ 1990).

59. Greenberg v Miami Children's Hosp. Research Institute, Inc, $264 \mathrm{~F}$ Supp. 2d 1064, 1074-1076 (SD Fla 2003).

60. American Medical Association. Opinion 2.08. Commercial use of human tissue. In: Code of Medical Ethics. Chicago: American Medical Association; 2007. Available from: http://www.ama-assn.org/ama/pub/ physician-resources/medical-ethics/code-medical-ethics/opinion208. shtml. Accessed June 1, 2012.

61. Gibson SF. The Washington University v. Catalona: determining ownership of genetic samples. Jurimetrics Journal. 2008;48:167-191.

62. Andrews L. Who owns your body? A patient's perspective on Washington University v. Catalona. J Law Med Ethics. 2006;34(2):398-407.

63. Revised Uniform Anatomical Gift Act. (Amended 2008. 1st ed: July 30, 1968). Chicago, IL: National Conference of Commissioners on Uniform State Laws; 2006. Available from: http://www.law.upenn.edu/library/ archives/ulc/uaga/april2006draft.pdf. Accessed June 1, 2012.

64. Washington University v Catalona, 490 F.3d 667 (8th Cir 2007), cert. Denied, 128 S. Ct. 1122. (2008).

65. Piccolo KM. In the wake of Catalona: an alternative model to safeguard research participants' interests in their biological materials. Univ Pitts Law Rev. 2008;69:769-788.

66. Boo M, Welte K, Confer D. Accreditation and regulation of cord blood banking. In: Broxmeyer HE, editor. Cord Blood. Biology, Transplantation, Banking and Regulation. Bethesda, MD: AABB Press (Advancing Transfusion and Cellular Therapies Worldwide); 2011:663-672.

67. Organisation for Economic Co-operation and Development (OECD). Guidelines for the Licensing of Genetic Inventions. 2006. Available from: http://www.oecd.org/science/biotechnologypolicies/36198812. pdf. Accessed June 1, 2012.

68. American Medical Association (Council on Ethical and Judicial Affairs). Who Should Profit From the Economic Value of Human Tissue? An Ethical Analysis. CEJA report E - A90. Chicago: American Medical Association; 1990. Available from: http://www.ama-assn.org/resources/ doc/code-medical-ethics/208a.pdf. Accessed. June 1, 2010.

69. WHO Expert Group. Expert Consensus statement on achieving self-sufficiency in safe blood and blood products based on voluntary non-remunerated blood donations (VNRBD). Vox Sang. 2012. Epub June 13, 2012.

70. Pauvert B. Le droit des éléments et produits du corps - ou les enjeux d'une réification silencieuse. [The law of bodily elements and products or the issues of silent reification]. In: Nicolas G, editor. Les Eléments et Produits du Corps Humain [The Human Body Elements and Products]. Paris: Les Études Hospitalières; 2011:11-26. French.

71. Rubinstein P. Cord blood banking for clinical transplantation. Bone Marrow Transplant. 2009;44(10):635-642.

72. World Health Organization (WHO). Informed consent form template for consent for storage and future use of unused samples [downloadable template]. Geneva: World Health Organization. Available from: http:// www.who.int/entity/rpc/research_ethics/Informed $\% 20$ consent $\% 20$ for $\% 20$ sample\%20storage.doc. Accessed June 1, 2012. 
Journal of Blood Medicine

\section{Publish your work in this journal}

The Journal of Blood Medicine is an international, peer-reviewed, open access, online journal publishing laboratory, experimental and clinical aspects of all topics pertaining to blood based medicine including but not limited to: Transfusion Medicine; Blood collection, Donor issues, Transmittable diseases, and Blood banking logistics; Immunohematology; Artificial and alternative

Submit your manuscript here: http://www.dovepress.com/Journal-of-blood-medicine-journal

blood based therapeutics; Hematology; Biotechnology/nanotechnology of blood related medicine; Legal aspects of blood medicine; Historical perspectives. The manuscript management system is completely online and includes a very quick and fair peer-review system. Visit http://www.dovepress.com/ testimonials.php to read real quotes from published authors. 